\title{
Print Workers and Revolutionary Rhetoric in Leipzig and Berlin, 1846-49
}

\section{Richard Skinner}

In March 1848, massive public demonstrations prompted the hereditary monarchs of many German states to grant an explicit recognition of fundamental civil liberties. The removal of restrictions on the freedom to speak, to assemble, and to publish provided an unprecedented opportunity for ordinary people to express their views and grievances in the public sphere. German artisans - the skilled manual labourers who were still the primary producers of many essential commodities - participated prominently in the popular movement; they sought to gain political representation and proposed solutions to the spread of poverty and unemployment, a crisis typically designated as "the social question." During the revolutions of 1848-49, artisans utilized independent publications to develop new forms of organization and solidarity; some began to ignore distinctions between the craft trades and to identify themselves as "workers," with common concerns and a common cause.

Most historians have acknowledged the political activism of German artisans during the revolutions of 1848-49, but have also emphasized their adherence to traditional economic relations, in particular to the regulatory functions of urban craft guilds. In some areas, masters and journeymen maintained craft loyalties and together demanded protection from merchant financiers and suppliers. ${ }^{2}$ Resistance to competitive free enterprise among artisans has been characterized as a "pre-capitalist" defense of customary rights; ${ }^{3}$ their enthusiasm for civil liberties and representative institutions in 1848 thus appears paradoxical and contradictory to theorists of "modernization." Others have noted a divergence of interests between organizations of masters and journeymen during the revolution, but have minimized the influence of republican and socialist ideas within such groups. ${ }^{4}$ More recent studies have recognized artisan discontent as a central component of radical democratic opposition, while explaining widespread hostility to capitalist development as the "rearguard struggle" of small producers seeking "access to the market."

In the years preceding the recent reunification of Germany, historians working in the German Democratic Republic advanced sharply contrasting perspectives. They argued that journeymen artisans had experienced capitalist exploitation in the early nineteenth century and had encountered socialist ideas while on the tramp in France and Switzerland. The extension of civil rights in the spring of 1848 , then, allowed an enlightened minority of artisans to begin 


\section{Left History 6.1}

educating and organizing their impoverished, proletarianized colleagues. Nonetheless allegiance to particular trades continued to inhibit working-class formation; 6 many craftsmen, still clinging to notions of artisan independence, mistakenly placed their confidence in the liberal leaders of "petty-bourgeois democracy," who discouraged discussion of the social question in order to preserve the unity of political opposition during the revolution. ${ }^{7}$ Thus East German historians, like western scholars, insisted upon the residual economic conservatism of politicized artisans, and assumed that an awareness of class identity among workers awaited the expansion of concentrated industrial production.

Such conclusions have been confirmed by a tendency to regard the construction of national political parties and trade unions as an index of class consciousness; local craft solidarities, however, also addressed the interests of workers, and certainly promoted collective action during the 1848 revolutions. ${ }^{8}$ A consideration of the texts produced by revolutionary artisans, furthermore, suggests that rhetorical figures and ideological references served as organizational tools; indeed some craftsmen propagated a language of class far in advance of any structural uniformity in their material and economic relations. Artisans in the printing trades occupied a strategic position in the popular movement of 1848 , and regarded themselves as a vanguard among politically active workers. In Leipzig and Berlin, they collaborated to publish periodicals that illuminated conditions within their own craft and commented on a variety of issues motivating revolutionary action. As they publicized their grievances, print workers in Leipzig and Berlin articulated the concerns of skilled labourers throughout the German states, and developed innovative techniques of cooperation, organization, and resistance. Their public thetoric, furthermore, advanced a sharp critique of competitive capitalism in conjunction with the popular assault upon the aristocratic regime.

\section{PRINTING AND REVOLUTION}

Historians have long recognized the printing press as an important agent of the fundamental political and social transformations known as "revolutions." A proliferation of printed materials accompanied the prolonged civil conflicts which effectively limited the authority of monarchs in seventeenth-century England and eighteenth-century France. In both instances, opponents of absolutism utilized the press to disseminate concepts of natural rights and liberties among common citizens. Although established authorities attempted to license and supervise the printing process, the authors of popular pamphlets influenced a dispersed audience and the publications of political clubs 
facilitated synchronized protest. The periodical press, by soliciting opinion from broad groups of subscribers and reproducing the deliberations of representative assemblies, contributed to an expanded sphere of public discussion. ${ }^{9}$

Periodical publications have usually been dismissed as unreliable sources of evidence for objective historical analysis, but recent studies of political culture have drawn attention to the press as a vehicle of ideological transmission. During the French Revolution, the periodical press provided immediate accounts of public events and allowed readers to consider the actions of political leaders. Newspapers and pamphlets explained and validated episodes of popular mobilization, and opened lines of communication between citizens and their representatives; as an ostensible indicator of the "people's will," the press undermined the legitimacy of successive governments. In order to consolidate their power, factions in the National Convention eventually restricted freedom of the press along with assemblies, festivals, and other democratic and participatory practices. ${ }^{10}$

Manual printing presses operated at low cost and enabled small enterprises to remain profitable during the French Revolution; print shops minimized risks by maintaining price agreements for subscriptions, and circulated most publications in editions of several thousand. Unrestrained by the concerns of investors and advertisers, publishers responded to the demand for political news and opinion and, along with papers subsidized by organized factions, contributed to the prevailing spirit of contention and recrimination. Some revolutionary publications conveyed the rhetoric of individual writers and editors; others stated the interests of specific associations or government ministries; larger commercial printing enterprises dispensed a wider selection of information and news. ${ }^{11}$ Although the periodical press should not be regarded as an entirely accurate reflection of public opinion, subscription arrangements did create a continuous relationship between authors and their anonymous readership. Content analysis of specific publications, therefore, provides some insight into the configuration of popular attitudes. ${ }^{12}$

Some historians, in an effort to reconstruct the revolutionary mentality of the working poor, have analyzed the pamphlets produced by radical journalists during the French Revolution, ${ }^{13}$ but others have been reluctant to regard such publications as manifestations of authentic popular culture. Subscription prices may have prevented poor readers from influencing the press market; however the sharing of costs, multiple use of single copies, public readings in clubs, libraries, and workshops, and high rates of literacy among urban artisans encouraged the popular reception of texts. Individual journalists, recognized as the authors of particular periodicals, could thus mobilize political activists behind coherent 


\section{Left History 6.1}

programs in moments of crisis. Yet the didactic approach of such writers, and their use of vulgar language to simulate the vox populi, may be viewed as techniques of manipulation rather than genuine expressions of a democratic political culture. ${ }^{14}$

One systematic study of the revolutionary press in Paris has delineated the contours of an "ideology of popular sovereignty." Motivated by political aims rather than an ethic of objective reporting, "radical democratic" journalists attempted to eradicate the social distinctions of the Old Regime and to propagate a commitment to "universal brotherhood." They portrayed the "people" of France as exemplars of virtue and morality, capable of reasoned political judgement and devoted to productive labour. As a social category, the "people" embraced the wide variety of manual workers - peasants, artisans, shopkeepers, and casual labourers - that constituted the vast majority of the French populace. The revolution accordingly involved a struggle between the "people" and a small minority of "aristocrats," marked by the exercise of privilege and the possession of wealth. In the language of radical democrats, "aristocracy" referred not just to the titled nobility, but to all groups - the upper clergy, officers, financiers, and lawyers - that defended particular liberties and held themselves aloof from the collective freedom of a unified citizenry. The establishment of popular sovereignty, for these writers, ultimately required the identification and elimination of aristocratic "egoists" at the tribunals of revolutionary justice. ${ }^{15}$

A similar rhetoric of popular protest appeared in the periodical and pamphlet literature that flourished during the European revolutions of 1848-49. Technical innovations and economies of scale had begun to transform printing enterprises in the early nineteenth century, but individuals and factions continued to rely upon manual modes of publishing. The publications of printers, in particular, deserve consideration as important points of intersection between ideological formations and popular mentalities; print workers, the actual producers of circulating texts, occupied a central position in the communicative network that linked the German states. ${ }^{16}$ During the revolutionary period, German printers attempted to form a cohesive national organization and provided an example of disciplined, coordinated action. In Leipzig and Berlin, print workers published periodicals for the explicit purpose of promoting solidarity within their own trade and among other disaffected craftsmen.

The precise extent of the reception of such texts, of course, cannot be measured, and they certainly should not be regarded as reliable indicators of general attitudes among artisans or even printers themselves. The language 
deployed in these publications, however, demonstrates that politically engaged print workers had moved beyond customary and localized forms of opposition by 1848 ; instead they drew upon a modern "repertoire of contention," in which planned assemblies and public petitions, directing claims toward national authorities and constituencies, took precedence over the spontaneous, parochial, and symbolic expressions of grievance characteristic of the Old Regime. ${ }^{17}$ Printers in Leipzig and Berlin, furthermore, found practical applications for their social vocabulary, and for their critique of free enterprise, in the cooperative publication of revolutionary texts. A close examination of their rhetoric reveals the printing process as a site where discursive and social practices converged.

\section{THE GERMAN PRINTING TRADES}

Print workers, as they confronted the revolutionary crisis of the late 1840's, relied upon their particular historical experience as practitioners of the "printers' art." German printers engaged in several forms of mutual aid that were typically codified in the regulations of craft guilds. The earliest statutes of the "book-printers societies" (Buchdruckergesellschaften) appeared in Frankfurt am Main in 1573, and mandated the collection of fines and contributions in central funds; these "Kassen" were intended to cover the costs of burials and illnesses, and to provide a modest payment (the Viaticum) to journeymen tramping in search of employment. ${ }^{18}$ Several key ordinances - referred to by printers as "das Postulat" - established norms for the length and procedures of training, for the ceremonial initiation of apprentices into the ranks of journeymen, and for the numbers of apprentices retained by master printers. Such regulations, confirmed by imperial, regional, and municipal authorities in the seventeenth and eighteenth centuries, were designed to control the supply of skilled labour in order to guarantee a secure existence for printers and their families.

Although some groups of printers; like most other craft guilds, maintained separate organizations for masters (Innungen) and journeymen (Brüderschaften), the Buchdruckergesellschaften generally remained open to journeyman participation. Printers cultivated a sense of distinction from the other artisan trades; they regarded themselves as practitioners of Kunst (art) rather than Handwerk (skilled manual labor), and adopted the terms Prinzipale and Gehilfen to distinguish masters and journeymen, rather than the conventional Meister and Gesellen. Gehilfen exercised significant rights of consultation, defined in the Postulat, with master printers. They educated apprentices, participated in courts of arbitration, and approved standard forms 
and levels of wages. ${ }^{19}$ Typical guild journeymen were required to embark upon a period of tramping, but Gehilfen preserved the custom voluntarily, especially in slack seasons when Prinzipale faced shortages of demand for their products; their entitlement to the Viaticum was recognized throughout the German states in the early nineteenth century. ${ }^{20}$

The corporate spirit of the printing trade was further solidified by ritual expressions of reverence for Johannes Gutenberg, whose workshop allegedly pioneered the use of interchangeable metal type in the fifteenth century. Printers celebrated the invention of the press at centennial festivals; icons and sculptures of the patron became objects of veneration for journeymen printers, the "Jünger Gutenbergs," who were known to refer to their workplaces as "temples." The Gutenberg cult strengthened craft allegiance among workers utilizing distinct skills: type-molders, pressmen, compositors, and colorists alike took pride in the exercise of the printers' Kunst, and in their unique proximity to the literate endeavors of scholars and intellectuals. ${ }^{21}$ Only book-binders established a separate guild in the sixteenth century, and remained aloof from the more inclusive printers' organizations.

This complex division of labor within the workshop further distinguished printing enterprises from the household crafts, and may have encouraged an expansion of scale. Traditional Handwerk produced its wares for individual customers in a limited local market, but print shops, from their inception, sought access to markets far beyond the city's walls. Successful master printers worked closely with merchants and developed marketing techniques; Prinzipale often functioned as entrepreneurs, employers, and directors of large establishments. Even before mechanization, print shops required substantial financial investment. The printing trade thus operated as a capitalist enterprise, as a form of manufacturing rather than Handwerk, in the early modern period. Print workers, consequently, rarely succeeded in becoming independent masters; most Gehilfen faced the prospect of life-long work as wage-earners.

Nonetheless Gehilfen benefited from the prosperity of the trade in the seventeenth and eighteenth centuries. With the spread of literacy and a general shift from intensive to extensive reading in the early nineteenth century, the demand for printed materials increased rapidly. Publishing was concentrated in the large German cities; in 1840 Berlin, with 41 print shops and 491 workers, and Leipzig, with 24 shops and 672 workers, were the leading centers of the printing industry. An erosion of corporate regulation, however, had facilitated expansion of scale in the early nineteenth century. Prinzipale, in collaboration with state authorities pursuing liberal economic reform, repealed the Postulat in several German states between 1800 and 1810. The introduction of free 
enterprise allowed publishers to rely upon the labour of unqualified apprentices in printing "factories" (Burschenfabriken). Gehilfen simultaneously lost their traditional rights of consultation, and their influence over training, job placement, and support funds waned. ${ }^{22}$ Although the activities of journeymen's organizations were restricted by imperial edict (1731), by Prussian ordinances $(1794,1800)$, and by legislation of the German Confederation $(1835,1840),{ }^{23}$ memories of the Postulat motivated a resurgence of collective action and facilitated the formulation of demands among print workers in the 1840 's.

The introduction of the iron "speed-press" - first at Leipzig's Brockhaus firm in 1826 - enabled publishers to increase their utilization of unskilled apprentices and to reduce the wages of pressmen. Brockhaus soon dismissed several operators of the wooden hand-press, and during the political agitation of 1830 , Gehilfen joined competing masters in protesting the operation of the machines. The speed-press began to be driven by steam engines in the 1830's and acquired a cylindrical design in the 1840's; such innovations allowed one "machine-master" with two apprentices to match the previous output of eight manual pressmen. Work alongside the speed-press consisted simply of laying out and removing sheets according to the tempo of the machine. Mechanization contributed to the enlargement of printing enterprises and further diminished the ability of Gehilfen to set up independent shops. ${ }^{24}$ Wider deployment of the speed-press in Leipzig provoked more demonstrations of hostility in 1845, and marked another step in the transformation of printing from "small-commodity" production into an "industrial" mode of operation. ${ }^{25}$

Mechanization, however, did not alter the skilled manual labour of typesetters until the 1880 's. Utilization of the speed-press required typesetters to work at night and at a faster pace. Consequently their complaints, in the 1830's and 40's, revolved around wage-rates and overtime. Intensification of labour contributed to the typesetters' perception of their condition as wage-workers with interests that ran counter to those of their employers, the Prinzipale. They continued, though, to maintain solidarity and occupational identity with the pressmen, based upon shared traditions and workplaces. Although mechanization did not directly threaten the employment of typesetters, the educational component of their tasks dissolved, as speed-up dictated the preparation of smaller portions of text. In contrast, the manual printing of oppositional papers and pamphlets in 1848-49 may have allowed both typesetters and pressmen to preserve an intellectual engagement with their work. 


\section{TYPOGRAPHIA: THE LEIPZIG PRINTERS BEFORE THE REVOLUTION}

The city of Leipzig was a major center for publishing and distributing German books and periodicals in the mid-nineteenth century. Leipzig's print workers, more densely concentrated in large enterprises than in any other locale, pursued a variety of strategies in defense of their interests during the prerevolutionary period (Vormärz). In the late 1830's several Leipzig Gehilfen were arrested for suspected contact with secret societies of German journeymen in Switzerland and France (Junges Deutschland, Bund der Geächteten). ${ }^{26}$ Committees of Gehilfen, in 1838, requested agreement on a fixed ratio of skilled workers to speed-presses in print shops, and in 1840 proposed a firm, detailed scale of wages (Tarif). In June 1840 the city's officials, notables, and communal guard attended a celebration of the Leipzig printers, who marched with banners and insignias to celebrate the 400th anniversary of the trade. Shortly after this "Gutenberg festival," print workers established an "educational union" with a reading library; as in many other German Bildungsvereine, regular evening meetings and lectures were intended to promote intellectual development, but also provided opportunities for organization and political discussion. ${ }^{27}$ In May 1846, 500 Leipzig Gehilfen signed a petition addressed to the legislature of Saxony. The document described deteriorating conditions within the trade, such as delayed payment, deductions from wages, dependence on credit, and arbitrary treatment by Prinzipale. The Gehilfen demanded a legal regulation of wages, and representation at assemblies of the master's Innung and on courts of arbitration.

The complete text of the printers' petition appeared in the first issue of Typographia, a weekly periodical published by Gehilfen who had formed a new "Gutenberg Union" in 1846. Typographia, the first German trade newspaper, was offered by subscription at a low price of 1 Thaler per year, and also circulated by hand in editions of several hundred. The paper - edited primarily by Oskar Skrobek, a typesetter at the Brockhaus firm ${ }^{28}$ — addressed all branches of the printing trade, including publishers; its contributors discussed a wide variety of issues that concerned print workers in the months immediately preceding the Revolution of 1848-49. Typographia thus reveals, in unmediated fashion, their perceptions of conditions within the Leipzig printing industry, and constitutes a significant surface on which the variegated discourse of the "social question" emerged. ${ }^{29}$

Like many other skilled artisans, printers suggested that free enterprise (Gewerbefreiheit) had given rise to damaging forms of competition in their own midst. ${ }^{30}$ In "Yet Another Bookprinter! Or the Blessing of Free Enterprise," a contributor to Typographia observed that Gehilfen could set up independent 
shops in Prussia upon payment of a modest fee. The author condemned the competition of such "intruders" and "meal-sharers," and claimed that these uncertified practitioners had reduced "the art to a common prostitute." Another article, entitled "Competition, the Cause of Multiple Misfortune," expressed similar objections to the shops of inexperienced printers, who gained profits by either driving down wages or dismissing their journeyman helpers. This writer recommended voluntary agreements to fix prices that would guarantee adequate earnings for both Prinzipale and Gehilfen. The interests of both workers and employers would be preserved, in this view, if competition involved quality rather than price. ${ }^{31}$

The regularity with which articles in Typographia counseled against the opening of small print shops indicates that many Gehilfen were attempting to establish independent enterprises. A commentator from Silesia ironically lamented the journeymen's eagerness to risk ownership "in order to come, freed from the burdensome pressure of the employer, to the easily satisfied goal - to receive a miserable, scanty livelihood." He explained that small workshops, able to carry out only the most basic tasks, relied on the labor of wives or untrained errand-boys, and thus diminished the prospects of employment for skilled Gehilfen. Independent journeymen, moreover, undermined the standards of their "partners in art" (Kunstgenossen) by supplementing their income through the exchange of petty commodities. Small firms which produced "at the pure cost-price of labor," this writer maintained contributed to a general "depression of prices" and gave validity to the maxim "the quantity must bring it." As competing shops turned to the cheaper labor of apprentices in order to lower prices, skilled print workers faced "so much the more prospect and certainty of having to knock about in the world lifelong as journeymen."

In early 1847 , "A Voice from the Working-Class" argued that the dissolution of guild regulations had reduced workers to a condition of "free slavery." Within the old guild structure, masters and journeymen reached joint agreements concerning requirements for tramping, the use of apprentices, and wage levels: "it was not permitted to give an arbitrary wage, but one definitely fixed by both sides." Any journeyman who favored free enterprise, this writer suggested, should consider "that also the employer is no longer bound, and thus he is completely abandoned to the arbitrary will of the former." By neglecting the experience of tramping and entering into early marriages, journeymen placed themselves at the mercy of factory employers who, no longer bound by the educational mandates of the guilds, also utilized untrained apprentices. "From this it now appears clearly," he concluded, "that Gewerbefreiheit is there only for the use of the employer, and that it allows the previous employers, the masters, 
to steadily disappear, and creates only money-aristocratic factory-lords."

Competitive free enterprise, in this analysis, had damaged traditional forms of solidarity among craftsmen and had brought about a fundamental change in social structure:

The actual artisan estate (Handwerkerstand) is now divided again into two classes: into masters and journeymen, or into employers and workers. The former brings the article, which is manufactured by the latter, to the market and values it at a high or low price according to whether the article is sought after or not; the worker however receives a sum in no way corresponding to the actual price of the article, the so-called wage. The latter class is the working class, which has become a daily topic. ${ }^{32}$

Subsequent articles in Typographia contributed further to the redefinition of artisans as "workers" (Arbeiter). One writer defined workers as manual laborers, whose skills distinguished them from members of "bourgeois society ... who with the help of their wealth make use of the labour of diligent hands." Another essay, "Concerning the Concept: Worker, Working Classes," similarly contrasted Arbeiter with their social opposites, "the idle and the lazy." Previously, great honours were reserved for the unproductive "privileged estates," but according to current public opinion, this writer contended, "labour is ... no longer underestimated and condemned as something unworthy of a free man ... but instead is respected as the common duty of every member of society." This recognition of work as a mutual responsibility, furthermore, implied that "the whole society consists, or should consist, of workers."

According to this writer, the identity of artisan producers had been sharply divided: some work "directly for commerce," bringing their own goods to market so that "what they receive for them, the price of the product, belongs to them," while others "first sell their labour to another, let themselves be given a wage, and thus renounce any share of the profit." Wage-relations, furthermore, were accompanied by a division of labour which enabled greater productivity in centralized workshops; workers no longer created a complete product (Arbeit), and instead only replicated separate parts for the "employers," "entrepreneurs," and "manufacturers" who supplied materials, tools, and machines and supervised both production and sales. The analysis, finally, arrived at a clear definition of Arbeiter:

One who labours in the service of another, because he himself lacks the necessary capital or intelligence to begin his own 
business, and therefore sells hislabour to the other at a price that is not directly determined by the price that everyone obtains for the product of labour, but by the greater or lesser supply of those who are likewise prepared to sell theirlabour in the same way.

The separation of wages and product prices had thus created a class of workers possessing no resources other than their own skilled hands; without capital or property, the worker lived "from hand to mouth," under conditions of virtual servitude. ${ }^{33}$

Another contributor observed that, for many members of the printing trade, the insufficient "price or wage for their work" compelled constant labour. This writer found no trace of concern, however, among prosperous Prinzipale, for whom "the money-sack (Geldsack) is the highest and moral conviction the last thing on earth." Minimal compensation, he asserted, had brought about the complete demoralization of otherwise assiduous artisans: "thus many a diligent and orderly worker, discontented because his honest efforts did not find deserved recognition, has become indolent in his work and has given himself over to disorderly conduct."

A consideration of the implications of machine production supplemented this cogent critique of wage-labor in Typographia. "What Influence Do the Machines Exert on the Trades and Humanity in General?," one article asked; this writer welcomed the application of machinery that, despite a temporary aggravation of unemployment, would eventually satisfy human needs. Machines, by reducing the reliance on sheer physical strength, would enable workers to turn to "another, more intellectual activity" and ultimately release them from "mentally deadening, purely mechanical labours." Machinery posed no danger to independent craftsmen, for whom "it is always the mind that leads the activity of the skilled hands." Technical progress, in this view, might even begin to eliminate the distinct class of workers, by eradicating the previous basis of social divisions - physical labour. ${ }^{34}$

The author of "On the Organization of Work" likewise looked beyond the provision of secure jobs and adequate wages and envisioned changes in the nature of labour itself. According to this article, the full development of human capacities should become the central purpose of work; this could be accomplished by arranging "the entire labour or production of all members of society" so that "the possibility is given to each one in particular to freely and completely unfold and develop all his powers and abilities." This writer insisted upon an innate human "drive to labour," and blamed the prevailing system of 


\section{Left History 6.1}

individual competition for rendering work invariable and unattractive: "in our relations, where each individual must pursue his private acquisition with anxiety, he is indeed chained to a certain labour." Under these conditions many workers had been "dulled, like machines"; the substitution of "common labour" for "solitary work and individualization," however, would allow a pleasant rotation of tasks, encourage sociable "rivalry," and restore enthusiasm to work.

Other contributors to Typographia suggested more specific modes of cooperation designed to improve their competitive position in a market dominated by financiers and large enterprises. "A Proposal for the Improvement of the Pecuniary Relations of the Working Class through Socialism" encouraged Gehilfen to contribute one Groschen every week to a common fund: "with this the basis for a print shop should be laid, that must expand with the capital coming in each year." Profits from the printers' own shop - "a property of the Gehilfen" - could then be used to support workers incapacitated by illness or accident. ${ }^{35}$ Another writer advised workers to elect committees to purchase food in bulk, using funds gathered by voluntary deductions from wages. The advantages of foresight and solidarity would become apparent through "such a common and cooperative collective action"; the author recommended that traditional funds for burials and illnesses be turned to the acquisition of heating, lighting, and other essential services. Even employers, he concluded, would benefit from the improved productivity of a unified, self-sufficient workforce.

Another article urged printers to look beyond "living together materially" and to cultivate a "spiritual socialization" (Vergesellschaftung). This writer emphasized the importance of collective action by drawing an analogy from the implements of the trade: "What is the single letter, the single question mark? A completely worthless piece of metal without sense and content. It only acquires its significance, and becomes a bearer of mind and thought, through socialization with the remaining letters." Citing abolitionism, temperance societies, and railroad construction companies as examples of cooperative organization, he appealed for a similar strategy of solidarity among printers. By utilizing the press to exchange views openly and to publicize their interests, Gehilfen could inform colleagues on the tramp about working conditions in other regions, and might eventually gain the right to vote. "Let us exchange our views, honorable comrades," he pleaded, "do not neglect to express and bring to the knowledge of your brothers everything you have in your hearts." 36

While most articles in Typographia addressed the economic concerns of print workers, its editors also displayed an acute political awareness prior to the outbreak of revolution. Contributors often adopted the contemporary language of politics to depict workplace conditions, and complained that the publicly 
professed liberalism of the publishers masked the harsh treatment of their workers. "Through arbitrary procedures," one writer observed, "they make themselves into little despots in their businesses, and thus at the same time trample on human rights." Some printers argued that their employers sought representation and education for themselves for purposes of financial gain: "You count yourselves ... for the most part among the liberals. Your liberalism extends only to the money-sack. You want to give laws, but do not follow the laws of humanity yourselves!" 37

Others compared the practices of employers to political absolutism and, much like republican political thought, equated tyranny with the pursuit of individual self-interest. One writer described an oppressive foreman "who rules like a tyrant in his realm and causes the helpers to shed many bitter drops of sweat for his own private advantage." Another printer, identifying himself as a member of the "working class," attacked the "system of enrichment" that operated to the advantage of employers: "the honest and painfully earned wage is very often cut for the worker, through the shameful arbitrary will, greed, and tyranny of the publishers." 38

In the months preceding the outbreak of revolution in 1848, the Leipzig printers, in Typographia, presented a critique of free enterprise that echoed the concerns of many other craft workers. Although they expressed more anxiety regarding the proliferation of small enterprises than the growth of factories, print workers identified the suspension of trade regulations as the central threat to artisan livelihoods. Competitive pressure dictated reductions in prices, which could only be achieved by the employment of unskilled apprentices and the payment of diminished wages. For independent artisans who sold craft items directly to local customers, the price of a finished product corresponded to an investment of labour and skill; in 1848 they still used the same word - Arbeit - to designate their work and its product. They understood, however, that divisions of labour had separated workers from their products and had shattered the independent existence and social identity of artisans: employers now confronted workers, as the buyers and sellers of commodified labour.

Perhaps because machinery had not yet threatened the employment of typesetters by duplicating their specific skills, Typographia suggested that a rational application of technology could foster intellectual activity by replacing repetitive physical labour. Contributors recommended a variety of "socialist" responses to the crisis of underemployment in the artisan trades: some envisioned a rational reorganization of socially necessary work; others called for the revival of traditional support funds and mutual aid, which could be used to establish cooperative enterprises; and the process of publication itself was cited 
as an example of solidarity and collective endeavor. The Leipzig printers, finally, incorporated the language of republican politics in their analysis of social conditions. They regarded "despotism" in the workplace as a violation of human rights, and viewed the disparity of incomes between workers and employers as an effect of "tyranny."

GUTENBERG: STRIKE AND REVOLUTION AMONG THE BERLIN PRINTERS

German printers certainly welcomed the attainment of civil liberties in March 1848; both Prinzipale and Gehilfen had long urged the abolition of censorship, which restricted the material and intellectual vitality of their trade. Typographia responded to the announcement of unrestricted press freedom by asking "What does the worker have to do now?," and advocated a strategy of publicity in order to achieve social reforms. The paper soon ceased to appear, however; the editor Skrobek, and perhaps many of Leipzig's printers themselves, began to collaborate in the production of a periodical expressing the views of "workers" in general - the Leipziger Arbeiter-Zeitung.

Print workers in other German cities continued to assert a more exclusive corporate identity during the initial phases of the 1848 revolution. Because of their immediate exposure to literary texts, they considered themselves an educated elite among workers; occupational loyalties remained strong among printers, and indeed may have contributed to unified action in disputes with their employers during the revolutionary period. In May 1848, print workers in Berlin began to publish a trade newspaper called Gutenberg, which reached 2,000 subscribers by the end of the summer; ${ }^{39}$ its editors hoped to facilitate the construction of a single organization for German printers. "Our desire," they explained, "is to make it into a general organ of all the brothers, and with its help to raise the established Book-Printing Union and to make it into a counterweight to the hostile efforts of capital." The editors of Gutenberg consistently supported a strategy of coordinated struggle: "nothing is more important for our corporation than centralization, that is, a point of unity for all the interests of book-printers and also type-founders."

In the spring of 1848 , print workers in Berlin, Leipzig, Breslau, and Dresden negotiated separate, provisional wage agreements with their employers, which led to an optimistic expectation that conflicts could be resolved within the publishing trade. The Leipzig Gehilfen, in an address to the publishers that appeared in Gutenberg, observed that "the enormous gap that still separates so many classes of workers from their employers is for us not at hand." ${ }^{30}$ In the following months, however, the Prinzipale attempted to revise 
and evade these contracts. As print workers in the major German cities organized themselves, an assembly at Mainz proposed a unified strike action to force the adoption of a standard wage-scale. ${ }^{41}$ On the eve of the strike, an article in Gutenberg criticized the failure to maintain solidarity in previous protests:

The nature of the social struggle is to split itself into as many individual struggles as there are branches of work, so that it is then all too easy for the workers to divide themselves and, in that each part pursues its goal exclusively and separately from the rest, each part is overcome.

The printers' campaign, in this view, illustrated a universal ethical maxim: "Every true human knows that the highest aim, the humanization of all persons, may be achieved only on the path of general fraternization (Verbrüderung) or association." In the language of Gutenberg, association referred to the national organization of printers, which the editors conceived as a vanguard of agitation among German workers in 1848. "Therefore hold firm, German brothers," they urged in the midst of the August strike, "persist until the last moment, brave fighters for the oppressed German workers, honourable members of the German Book-Printers' Association." 42

Gutenberg consistently interpreted the organized strike action of the print workers in 1848 as a response to the introduction of competitive free enterprise. Shortly after the beginning of the strike in August, a lengthy article in Gutenberg pointed to the historical precedent for a uniform wage-scale - the Postulat:

this formed the dam against the arbitrary will of the print-lords: they had to respect and acknowledge human rights, the right of the individual as well as of the whole society; in respect to business, no print-lord could dig his own grave, let alone that of the journeyman, the prices of labour might not be lowered without permission of the society, the Postulat likewise did not allow too many apprentices, the situation was a happier one; for the German printers' society had at that time a clear democratic constitution.

When the masters in Berlin, however, decided to eliminate the Postulat in 1808, the "slow social murder" of the print workers began. During the 1848 strike, Gutenberg continued, printers began to recognize the danger of unlimited individual liberty. The editors posited a notion of "legal freedom" in contrast to unregulated free enterprise, and advocated a forceful reappropriation of rights that had been violated by competitive employers: 
The Postulat should only have been freed from the slag, ${ }^{43}$ but by no means dissolved. Into its place stepped despotism, the absolutism of the printlords, moreover as a result of free enterprise came the murderous competition in the cheapness of labour, all conceptions of a reorganization remained unnoticed by the print-lords as well as the governments, they were ignored, the misery finally reached a point of culmination, then the unavoidable happened; the natural right had to be acquired, extorted, once again taken.

The national network of organizations constructed by print workers in 1848 did not seek to revive comprehensive guild regulations, but instead aimed to establish a standard scale of wages to mitigate the impact of competitive pressures. The strike, however, foundered after several weeks, as print workers and employers in Frankfurt am Main arrived at a separate contract and founded a new organization. Gutenberg objected to this agreement, precisely because it failed to establish definite wages and prices; they professed astonishment at the "uncertainty" of the contract, which "opens the gate to the arbitrary will of the employers and allows an almost unlimited latitude to mutual overreaching through free competition." ${ }^{44}$ The Leipzig union condemned this development as a betrayal of the workers' interests and a revival of narrow corporate solutions: "Have we not sacrificed the general fraternization (association), and to whom? To the corporation, or much more, to corporations." In retrospect the national strike appeared ill conceived and premature to the Leipzig printers, who appealed for restored unity and warned their colleagues to reject the designs of "incorporated publishers."

An October article from Berlin further developed this antithesis of "association" and "corporation" and inflected the terms with political references. Rather than supporting print workers in the "action of association," the author contended, employers preferred "to supplant association with corporations"; their strategy demonstrated a renewal of the "old despotic force" which reduced productive labourers to "hungry servants." An effective printers' association, he suggested, should draft statutes to govern the activities of subordinate local unions. For this writer, the creation of a national trade organization paralleled the movement toward German political unity. Both were necessary antidotes to the persistence of financial privilege: "The corporations are the same in the association as the 38 sovereign states in a unified Germany; they are incubators of separatism, of selfishness, and of the money-aristocracy." 45

The failure of the 1848 strike damaged the prospect of corporate reconciliation between publishers and print workers. Gutenberg continued to 
portray Gehilfen as victims of capitalist relations, and advocated association as a vehicle for social principles that directly contradicted exclusive guild prerogatives:

If an association or even a corporation has any sense at all, it must be based on the principle of true freedom, actual brotherhood, and the fully equal rights of all individual members. If this is not the case, a corporation is nothing more than a fashionably trimmed guild.

Printers often presented their economic claims as natural rights; striking workers, according to Gutenberg, "consider it their duty to unanimously and firmly enter the lists for the great principle of socialism, for their human rights and those of their German brothers." ${ }^{\text {46 }}$ The collapse of the national strike in August also demonstrated that civil liberties would not lead directly to improved wages or working conditions. In an epitaph to the failed strike, Gutenberg cited the popular slogan of the French Revolution to indicate the ultimate goal of the print workers:

Such is the history of our struggle for the rights of labour and the workers and of the treachery of our own brothers. The play is over, the old principle of the rule of money is lord of the battlefield; the new principle of justice and brotherhood had to yield, but it still lives. A new drama begins, whose last act will close with the victory of liberty, equality, and fraternity.

In the aftermath of the aborted strike, the rhetoric of Gutenberg moved beyond the specific concerns of printers and began to portray the revolution as continuing conflict between broad social classes. During the autumn of 1848 , tensions mounted throughout the German states: the impotence of the Frankfurt Assembly was revealed in September as the Prussian government separately agreed to the Treaty of Malmö; violent skirmishes between workers and municipal authorities occurred in Chemnitz and Berlin; Austrian and Croatian troops subdued the revolution in Vienna and summarily executed Robert Blum, Leipzig's popular democratic representative. In October Gutenberg referred to a great struggle between the "working class" and an idle "aristocracy" that monopolized positions of honor and public responsibility in a "tyrannical society." Gutenberg defined the nineteenth-century aristocracy as "the totality of those who want to consume without producing, to live without working"; engagement in productive labour, however, characterized "the workers and propertyless, which are by far the largest part of humanity, the whole mass of 
those who produce without consuming and work without being able to live." Gutenberg also regarded employers, who denied education to workers and refused to acknowledge their natural rights, as members of the aristocracy. A camel will pass through the eye of a needle, the printers concluded, sooner than "the clan of aristocrats of money and birth voluntarily and without spilling blood allow the worker to share in the human rights due to him by God's mercy."47

In an article from November 1848, Gutenberg widened the scope of its economic analysis still further. Previously the editors had attributed competition over the price of labour to free enterprise, but now they began to refer to the triumph of "capital" and the rise of a bourgeois class:

With the collapse of noble rule the bourgeoisie (Bürgerthum) achieved not only political rights, its whole method of production became different, and into its romantic grave the nobility pulled the guild-system and gradually the last remains of medieval barbarism. With the bourgeoisie the dominance of capital through free competition steps forth.

The article predicted that the revolutionary effort to create a unified nation would ensure the full development of Germany's Bürgerthum, and "that our time will succeed in destroying the medieval craft-relations, wherever they ... still exist, and will call forth on every side a unity in our various national institutions and remove the last remains of the rule of nobility." The printers of Gutenberg, despite their endorsement of stable wages and prices, apparently desired no resurrection of comprehensive guild controls, and indeed viewed the competitive conditions of free enterprise as an accomplished fact. They looked forward, though, to a future in which artisan workers would regain their independence, in which "social freedom" would replace the free competition characteristic of capitalist development.

In other articles, Gutenberg argued that changes in the frame of government would not ensure the provision of work for all citizens or any actual improvement in material conditions; workers would have little prospect "under a constitutional monarchy or also under a bourgeois republic (both signify: under the rule of capital) of acquiring a guarantee of work or even a labour ministry for the proper determination of wages." 48 The editors of Gutenberg suggested that a removal of property qualifications for political participation would not suffice to overcome the fundamental antagonism between the bourgeoisie and the working "folk":

For do we not see that in the time when the folk has achieved political 
freedom, its social opposition to the class of capitalists only steps forth more clearly, that it now throws itself with all its active strength into the acquisition of social freedom!

The exercise of political rights, according to Gutenberg, provided the means for attaining an "independent existence"; printers, therefore, should stand beside small producers and workers to resist "the power of capital and free competition." Enfranchisement of all working citizens, Gutenberg maintained, would enable a more significant transformation, and the folk

will no longer wish to depend on its fellow citizens for wages and bread, it will no longer wish to quietly starve and accept alms from sympathetic hands, it will necessarily create for itself a new, secure existence. And from this moment on we will not forget that it makes no more rebellion, it makes revolution!

As the forces of reaction began to move against the centers of the revolution in the fall of 1848 , voices in the oppositional press began to suggest the necessity of a "second revolution" to preserve the achievements of March. The Gutenberg printers expected a renewed confrontation to end the hegemony of capital; "the bourgeois-domination will last only until the next revolution," they asserted, even though the general public believed "that the next revolution cannot be social or social-political, but only purely political." The failure of the proposed constitution to address the crisis of unemployment and poverty, the printers insisted, would only intensify class hostility, and

must necessarily have as a result the separation of the whole folk into bourgeois or capitalists and proletarians, since it contained not a single word about the organization and guarantees of labour or even a guarantee of existence from the side of the state.

Because the authorities installed by the March events and the Frankfurt Assembly itself had failed to address the social question, Gutenberg suggested, workers were unwilling to align with "a cowardly bourgeoisie — which has only taken possession of weapons in order to turn them on its poor brothers."

Gutenberg, however, also transposed the conflict between capital and labour into more inclusive terms; since March, in its account, the primary contending parties had been the "folk" and the "crown and camarilla." The people's representatives in Frankfurt mistakenly legitimated the monarchy 


\section{Left History 6.1}

through negotiations, but "the crown remains what it always was, the representative of privilege and force." The folk could do nothing but protest while the Frankfurt Assembly ceded its rights to the crown and the court party attempted to restore absolutism "under a constitutional disguise." The printers contended that the bourgeoisie had abandoned the popular cause and joined a monarchist majority in the assembly - a betrayal that began at the inception of the revolution:

Yes, the folk stood in a considerable incongruity, for the weapons had been mostly delivered into the hands of the bourgeoisie, who had passively observed the uprising on March 18, and the majority of representatives were not true representatives of the folk, who desired general freedom and the equal rights of all citizens, but representatives of the bourgeoisie, who were striving for freedoms and privileges for capital.

The claims of capital and the crown, Gutenberg concluded, must ultimately give way to "popular sovereignty"; until then a condition of anarchy prevailed, which could only be resolved "through a bloody struggle, through a revolution." 49

The Berlin printers, in Gutenberg, presented a critique of free enterprise that paralleled the analysis of their Leipzig colleagues: the dissolution of traditional agreements regulating prices, wages, and the use of apprentices had unleashed a destructive competition that devalued their skills. However this critique, which surfaced repeatedly in the petitions and programs of numerous artisan organizations in 1848-49, should not be construed as a nostalgic appeal for the revival of local guilds. Although established master craftsmen may have regretted the passing of "corporate" society, journeymen consistently rejected guild authority as a vestige of privilege and supported the revolutionary campaign for civil and legal equality. Thus the Gutenberg printers carefully prescribed the subordination of local "corporations" and the primacy of the national "association." The central aim of the printers' association was to improve their bargaining position through coordinated protest and the formulation of uniform demands; thus print workers, through their engagement in the crisis of $1848-49$, developed several strategies that were later adopted by national German trade unions.

Like the Leipzig printers, the authors of Gutenberg infused their economic analysis with the terminology of radical politics; they referred to employers as aristocratic "lords" and to capitalist competition as a new "despotism." The rhetoric of Gutenberg often returned to the social vocabulary popularized by radical democratic journalists during the French Revolution. For print workers, 
the crisis of 1848 portended the demise of the hierarchy of estates, of social distinctions enshrined in law, of political power determined by patronage and privilege - all signified by "aristocracy." The revolution represented a recognition of the natural rights of the people, or the "folk," and their inclusion in a nation of citizens guided by elected representatives. Upon this older and primarily political interpretation of revolutionary conflict, however, the Berlin printers superimposed an alternative language of class, which opposed the "bourgeoisie," the possessors of capital, to "proletarian" labourers and the working folk. Rarely acknowledged by historians of the 1848 revolutions, these categories also appeared prominently in the publications of other workers' associations and "democratic" clubs. The language of class not only indicated an understanding of capitalist productive relations among German artisans, but also referred to the widening perception, within the popular revolutionary movement, that the procedures of representative government had been compromised, and that the notable Bürger deliberating in Frankfurt would offer no solution to the social question.

\section{CONCLUSION}

By the end of 1848, print workers in both Leipzig and Berlin had established cooperative associations designed to facilitate the production of independent publications. Despite the objections of the Leipzig publishers' Innung, which insisted that Gehilfen should work only "on their own account," Saxony's Interior Ministry authorized Leipzig print workers to establish an enterprise (Vereinsdruckerei) that would provide work for their unemployed colleagues. In accordance with the proposals for cooperative production that had appeared in Typographia, the Leipzig organization in 1849 assumed responsibility for the publication of Die Verbrüderung, a paper seeking to draw all kinds of German labourers into the local affiliates of the "Workers' Fraternization," an open and inclusive national association. The editors of Gutenberg, following upon the experience of the 1848 strike, continued to advocate the construction of a national union for print workers alone, and drafted statutes intended to establish a permanent, centralized organization the Gutenbergbund. Customary forms of mutual aid, such as the collection of funds to support tramping journeymen, appeared prominently among the founding principles of the exclusive printers' organization in Berlin. ${ }^{50}$

The Berlin printers' maintenance of an organizational structure separate from the more comprehensive "Workers" Fraternization" should not be viewed as a rejection of solidarity with workers of other trades. Both groups attempted 
to affiliate local artisan associations with new national organizations, and to coordinate their efforts through periodical publications; they planned to build upon existing craft identities, not to replace them. Membership in one organization did not preclude participation in another, and many workers undoubtedly supported clubs with an explicit political orientation without abandoning allegiance to their trade. An emphasis on traditional forms of mutual aid in organizational statutes not only assisted recruitment, but also shielded artisan associations from charges of revolutionary political activity in periods of repression.

The endorsement of "freedom of association" by the established regimes in the spring of 1848 allowed artisan workers to enter the public sphere and to experiment with numerous models of collaboration. Their manifold responses were paralleled by the variable significance of key rhetorical expressions. "Association," for example, frequently specified the establishment of producers' cooperatives in the revolutionary period, while for the Gutenberg printers, the term suggested an alternative to the exclusive prerogatives of local guilds; these usages were complementary, not antithetical. The familiar dichotomies of historical analysis - traditional/modern, reformist/ revolutionary, capitalist/socialist - rarely capture the ambiguity and complexity of public language which, especially in periods of intense political and social conflict, itself becomes an arena of contested meanings.

For similar reasons, the vocabulary of protest cannot be convincingly attributed to the influence of individual writers and theorists. The editors of the popular press in 1848-49 freely appropriated rhetorical elements of the French revolutionary tradition, and the socialist prescriptions of Fourier and Blanc resurfaced in several German publications. Proposals to solve the crisis of poverty and unemployment through the "organization of labour" appeared repeatedly, but their specific content varied in response to particular conditions, expectations, and negotiations. The language of class circulated widely in the radical press, but surely not as a result of Marx's ineffective agitation among workers in Köln, who published an independent periodical during the revolutionary months. The typesetter Stephan Born, a central figure among the Berlin and Leipzig workers and an editor of both Gutenberg and Die Verbrüderung, had collaborated with Marx and Engels in 1847, but his organizational efforts and advocacy of cooperative associations later ran counter to their focus on political struggle. Born's editorial work must be understood as a product of extensive collaboration with craft workers in the Berlin "artisan society" (Handwerkerverein), rather than as a vehicle of some putative orthodoxy. Likewise, elements of radicalism in authentic artisan publications 
proceeded from the collective experience of capitalist competition in deregulated urban economies; they were not simply imposed, from above, by conspiratorial leaders and factions.

After the decisive defeat of militant insurgencies in the summer of 1849 , the restored regimes enforced repressive measures that curtailed the activities of workers' associations and the oppositional press. The collapse of the popular struggle for representative government and social equality, however, cannot obscure the emergence of a democratic political culture in the German states during the revolutions of 1848-49. Indeed the wide participation in practical political action, in the construction of representative local, regional, and national organizations to articulate interests and demand reforms, may constitute the central legacy of the mid-century revolutions, In urban populations exceeding 60,000 (Leipzig) or 400,000 (Berlin), the efforts of several hundred printers, or the impact of several thousand copies of a periodical, may appear inconsequential. Print workers, however, acted in conjunction with other organizations of discontented artisans who likewise relied upon publicity and projected a similar language of protest. In Leipzig, tailors and cobblers also constructed associations for cooperative production, and the periodicals of democratic clubs voiced a similar interpretation of the revolution as a conflict between broad social classes. Enthusiasm for cooperative enterprises seems to have been most prominent in the LeipzigBerlin network of associations; in southern and western German states, divisions between masters and journeymen were not as sharp, craft allegiances remained strong, and many artisans supported more moderate proposals for representative federations of reformed guilds. In the summer of 1848, though, the exclusion of journeymen delegates from the Frankfurt Artisan Congress gave impetus to the creation of more inclusive and extensive organizations, to promote the common interests and identity of "workers."

In order to serve as a vanguard among workers, printers certainly drew upon their experience with capitalist productive relations; yet their important contribution to the revolutionary movement also arose from their specific location in the circuit of communication, as recipients and producers of ideas and texts. In addition to formulating and disseminating the concerns of their trade, printers served as the editors of periodicals that aimed to forge a common identity among workers of all crafts. Through the periodical press, print workers transmitted ideological currents and rhetorical expressions that encouraged new forms of solidarity and that promoted the construction of voluntary associations to pursue both political and economic ends. Along with other German workers, they utilized civil liberty to speak for themselves, to develop and communicate 


\section{Left History 6.1}

an independent consciousness of their material deprivation and social identity.

Devotion to their particular craft contributed to the printers' attempt to present a unified front against their employers in 1848; at the same time, however, references to the "working class" reflected an awareness that artisan solidarity had been fragmented by tensions between capitalist owners and wageearners. Print workers blamed free enterprise for the overpopulation of their trade and declining wages. They advocated a uniform wage-scale to stabilize and standardize rates of pay, but declared other aspects of the guild economy obsoletc. Printers, engaged in the cooperative publication of revolutionary papers, were among the first workers to attempt associated production. Association also referred to the national organization of printers, envisioned as an example of brotherhood and economic equality rather than a corporation reconciling the interests of masters and journeymen. Print workers, like other artisans, sought political enfranchisement in order to gain respect as equal citizens, and to achieve economic reforms that would improve their material condition; they defined the revolution as a struggle for popular sovereignty, in which the working folk challenged the dominant forces of aristocracy, monarchy, and capital.

1 Hermann Beck provides a useful survey of historiography concerning the "pauperization" crisis in The Origins of the Authoritarian Welfare State in Prussia; Conservatives, Bureaucracy, and the Social Question, 1815-70 (Ann Arbor 1995).

${ }^{2}$ Friedrich Lenger, Zwischen Kleinbürgertum und Proletariat: Sozialgeschichte der Düsseldorfer Handwerker im 19. Jahrhundert (Göttingen 1986).

${ }^{3}$ Barrington Moore, Jr., Injustice: The Social Bases of Obedience and Revolt (White Plains, N.Y. 1978), 147-71.

${ }^{4}$ Paul H. Noyes, Organization and Revolution: Working Class Associations in the German Revolutions of 1848-49 (Princeton 1966).

5 Jonathan Sperber, Rhineland Radicals: The Democratic Movement and the Revolution of 1848-49 (Princeton 1991), 467.

6 Walter Schmidt, "Zu einigen Fragen der sozialen Struktur und der politischen Ideologie in der Zeit des Vormärz in der Revolution von 1848/49," Beiträge zur Geschichte der Arbeiterbewegung (1965, H.4), 645-60.

${ }^{7}$ Rolf Weber, "Die Beziehungen zwischen sozialer Struktur und politischer Ideologie des Kleinbürgerthums in der Revolution von 1848/49," in Die deutsche Revolution von 1848/49, ed. Dieter Langewiesche (Darmstadt 1983), 278-90.

${ }^{8}$ See Michael J. Neufeld, The Skilled Metalworkers of Nuremberg: Craft and Class in 
the Industrial Revolution (New Brunswick, N.J. 1989).

9 Elizabeth L Eisenstein, "On Revolution and the Printed Word," in Roy Porter and Mikulas Teich, eds., Revolution in History (New York 1986), 186-201.

${ }^{10}$ Jeremy D. Popkin, Revolutionary News: The Press in France, 1789-99 (Durham, N.C. 1990), 2-5, 10-11, 171, 179.

" J. Gilchrist and W. J. Murray, eds., The Press in the French Revolution (New York 1971), 1-10.

12 Jack R. Censer and Jeremy D. Popkin, eds., Press and Politics in Pre-Revolutionary France (Berkeley 1987), 11-12.

13 Albert Soboul, The Sans-Culottes: The Popular Movement and Revolutionary Government, 1793-94, trans. Remy Inglis Hall (Princeton 1980).

14 Popkin, 78-82, 145-46, 157.

15 Jack Richard Censer, Prelude to Power: The Parisian Radical Press, 1789-91 (Baltimore 1976), 38-51.

${ }^{16}$ Robert Darnton suggests that the social history of ideas depends upon an analysis of the "communications circuit"; for example see "What is the History of Books?" and other essays in The Kiss of Lamourette: Reflections in Cultural History (New York 1990).

${ }^{17}$ This argument has been extensively developed by Charles Tilly, referring to British political processes, in Popular Contention in Great Britain, 1758-1834 (Cambridge, Mass. 1995).

${ }^{18}$ Rolf Stümpel, "Buchdrucker," in Reinhold Reith, Lexicon des alten Handwerks: Vom späten Mittelalter bis ins 20. Jahrhundert (München 1990), 51-52.

19 Jürgen Kocka, Arbeitsverhältnisse und Arbeiterexistenzen: Grundlagen der Klassenbildung im 19. Jahrhundert (Bonn 1990), 384.

20 Gerhard Beier, Schwarze Kunst und Klassenkämpfe: Geschichte der Industriegewerkschaft Druck und Papier und ihrer Vorläufer seit dem Beginn der modernen Arbeiterbewegung, Bd. I (1830-90) (Frankfurt a.M. 1966), 100-101.

21 Kocka, 386-87; Stümpel, 45-54.

${ }^{22}$ Kocka, 383-88; Beier, 105-06.

${ }^{23}$ Elizabeth Todt and Hans Radant, Zur Frühgeschichte der deutschen Gewerkschaftsbewegung, 1800-49 (Berlin 1950), 42, 46; Beier, 41.

24 Kocka, 388; Beier, 56-68.

25 Hartmut Zwahr, Zur Konstituierung des Proletariats als Klasse: Strukturuntersuchung über das Leipziger Proletariat während der industrieller Revolution (Berlin 1978), 86-87.

26 Kocka, 390-91; Beier, 116, 188-89.

27 Todt and Radant, 101-02; Beier, 47-53, 180.

28 Todt and Radant, 101-02; Beier, 190-95.

${ }^{29}$ For an explanation of "discursive formations" and "surfaces of emergence," see Michel Foucault, The Archaeology of Knowledge, trans. A. M. Sheridan Smith (New York 1972).

${ }^{30}$ Gewerbefreiheit has often been translated as "occupational freedom"; at issue, however, was not the liberty to choose a trade, but the ability to engage in craft production without the authorization of local guilds. "Free enterprise" conveys the broader range of connotations. 


\section{Left History 6.1}

${ }^{31}$ Typographia, \#3, 15 August 1846; \#15, 7 November 1846.

${ }^{32}$ Typographia, \#21, 16 October 1847; \#1, 2 January 1847.

${ }^{33}$ Typographia, \#3, 30 January 1847; \#8, 10 April 1847.

${ }^{34}$ Typographia, \#9, 21 April 1847; \#12, 5 June 1847.

${ }^{35}$ Typographia, \#17, 21 August 1847; \#13, 24 October 1846.

${ }^{36}$ Typographia, \#3, 30 January 1847; \#2, 16 January 1847.

${ }^{37}$ Cited in Beier, 194.

38 Typographia, \#12, 5 June 1847; \#13, 26 June 1847.

${ }^{39}$ Beier, 197-98, 233-34.

${ }^{40}$ Gutenberg, \#3, 19 May 1848; \#1\&2, 13 May 1848.

${ }^{41}$ A detailed summary of the printers' strike appears in Todt and Radant, 167-85.

42 Gutenberg, \#13, 29 July 1848; \#15, 12 August 1848.

${ }^{43}$ The "slag" (Schlacke, the refuse of molten metal) is perhaps another reference to the craft techniques of molding and setting type. Here the printers are advocating a revision, rather than the elimination, of trade regulations.

44 Gutenberg, \#16, 19 August 1848; \#19, 9 September 1848.

${ }^{45}$ Gutenberg, \#21, 23 September 1848; \#23, 7 October 1848.

${ }^{46}$ Gutenberg, \#25, 21 October 1848; \#15, 12 August 1848.

${ }^{47}$ Gutenberg, \#18, 2 September 1848; \#23, 7 October 1848.

${ }^{48}$ Gutenberg, \#29, 18 November 1848; \#26, 28 October 1848.

${ }^{49}$ Gutenberg, \#29, 18 November 1848; \#30, 25 November 1848.

${ }^{50}$ Beier, 289-90, 294. 